\title{
The Ideology of Russian-Language Jihadism before ISIS': Treating the Soviet Past as the Origin of Post-Soviet Radicalism
}

\author{
Translation by Isaac Stackhouse Wheeler
}

DOI: $10.22394 / 2311-3448-2018-5-1-82-106$

Danis Garaev - Department of History, European Studies and Religious Studies, University of Amsterdam (Netherlands). danis.garaev@ gmail.com

This article is devoted to the origin and development of the propagandist ideology of Russian-language jihadism. It develops the idea that the jihadism in Russia should be considered not so much in the context of the Islamic issue or as a result of the influence of foreign countries, but rather as an example of post-Soviet radicalism, formed on a native ideological and intellectual base. The article states that this meaningfully diverse ideology originated under the influence of Soviet and post-Soviet intellectual traditions, which made this ideology so effective in the Russian context.

Keywords: jihad, post-socialism, radicalism, Islam, jihadism.

7 HE First (1994-1996) and Second (1999-mid-200os) Chechen Campaigns, which began with the proclamation of an independent but universally unrecognized Ichkeria and concluded with a struggle to create an Islamic state in Chechnya, led to the appearance of the so-called Caucasian Emirate in $2007 .^{2}$ This extremist organiza-

Originally published in Russian as: Garaev, Danis (2017) "Ideologiya russkoyazychnogo dzhihadizma do IGIL: recepciya sovetskogo kak rozhdenie postsovetskogo radikalizma," Gosudarstvo, religiia, tserkov'v Rossii i za rubezhom 35(3): 170-201.

This project was supported by the Dutch Scientific Organization (project 360-70-490), The Russian Language of Islam.

1. Banned in the Russian Federation by decision of the Supreme Court of the Russian Federation No. AKPI 14-1424C dated 29 December 2014.

2. Banned in the Russian Federation by decision of the Supreme Court of the Russian Federation No. GKPI 09-1715 dated 8 February 2010. 
tion fought for a Sharia-based state throughout the Northern Caucasus under the banner of jihad.

As a result, an entire generation of jihadist ideologues appeared in this region during the post-Soviet period. Because they had fought against the Russian authorities, they were an object of particular interest to the Russian public, especially those (both Muslim and nonMuslim) who were inclined toward radicalism. These ideologues included such figures as Shamil Basaev, Iasin Rasulov, Said Buriatskii, Anzor Astemirov, Movladi Udugov, Timur Mutsuraev, and many others. These people were very different, but the one thing they had in common was the ability to talk about jihad in a way that Russian-language audiences found accessible. Furthermore, all of them understood jihad to mean armed struggle against the Russian authorities. Propaganda methods and arguments in support of jihad differed somewhat in different periods, which made this ideology quite diverse in terms of content, yet it was, in all cases, based on a military interpretation of jihad as a form of opposition against Moscow.

Although the Arabic word "jihad," which translates as "effort," has a rather wide range of interpretations, from struggling against one's own spiritual defects to armed conflict, this article will not discuss the religious and linguistic debates surrounding this term. The question of what the term "jihad" means in the context of the events in the Northern Caucasus will be left to the judgment of Islamic theologians. From a researcher's perspective, the interesting question is how the aforementioned ideologues made this particular term the central category around which they built their discursive strategies.

The fact that they chose jihad as the main theme of their statements also provides grounds to refer to them as jihadist ideologues and to the propaganda they generated as jihadist ideology. This article is dedicated to answering the following questions: What made jihadist propaganda popular and influential in Russia during the $1990 \mathrm{~s}$ and 2000s? What factor played the decisive role? Framing the question in this way automatically makes it necessary to consider what the actual content of jihadist ideology was during that period.

Texts by several famous Russian jihadist ideologues from the $1990 \mathrm{~s}$ and 2000 are the subject of my study. In these texts, ideologues call for jihad and provide various justifications for and interpretations of the idea. ${ }^{3}$ The analysis will focus on the semantics and ideological

3. Since the majority of the texts analyzed in the course of the author's research project in the Netherlands may not legally be distributed in Russia, direct quotations will be avoided here. 
foundations of these texts: the terms and symbols they use, the ideas and authorities they refer to, and the themes that preoccupy them.

I emphasize this particular historical period because the emergence of the so-called "Islamic State" (ISIS) in the Middle East during the 2010 s was followed by a significant drop in extremist activity in the Northern Caucasus, since the bulk of this movement's military and intellectual power shifted to Syria and Iraq. Without studying what this ideology was during the first twenty years after the collapse of the Soviet Union, however, we are unlikely to understand the problems of today.

Considering the breadth of the subject and the space limitations of a single article, I will focus on a few extremely important texts produced by ideologues from the Northern Caucasus to justify armed jihad. Specifically, they include texts by figures such as Zelimkhan Yandarbiev (1952-2004), the former president of Ichkeria; Movladi Udugov (born 1962), the creator of Kavkazcenter.com, ${ }^{4}$ the main mouthpiece for Northern Caucasian jihadists; ideologue of the Dagestani "Sharia" movement, Iasin Rasulov (1975-2006); the leader of the Karbardino-Balkar Jamaat and subsequently Sharia judge of the "Caucasian Emirate” Anzor Astemirov (1976-2010); as well as Said Buriatskii (also known as Alexander Tikhomirov, 1982-2010), one of its ideologues and most striking speakers. This selection of authors was governed by the fact that they belong to different groups at different stages of armed resistance in the Northern Caucasus, with different kinds of educational and professional experience, and have reached different levels of notoriety among the general public.

All of the texts under study were written in Russian. The very fact that not only the aforementioned authors, but also the other jihadist leaders and ideologues of the Northern Caucasus primarily wrote their texts in Russian is sufficient grounds to mark this phenomenon as a post-Soviet one, since Russian became the primary language of Islam in Russia after the collapse of the Soviet Union (see Kemper and Bustanov 2015, 211-221; Bustanov and Kemper 2013, 259-77).

The relevance of this subject is dictated by the destructive effect of this phenomenon on both Russia and the global community. A significant portion of current threats to international security are connected with the phenomenon of jihadism; therefore, a comprehensive and focused study of these problems will make it possible to develop a better understanding of the phenomenon, and consequently to find the key to solving them.

4. The source was classified as extremist by decision of the Nikulinskii District Court of the City of Moscow, dated 12 September 2011. 
The main thesis of this article is that jihadism must be not be primarily examined in the context of Islamic issues, or regarded as a consequence of foreign influence, which has been commonplace for the majority of studies, but rather as an example of post-Soviet radicalism, with domestic ideological and intellectual foundations.

More specifically, Russian-language jihadist ideology from the period contained obvious Soviet and post-Soviet narratives, ideas, themes, and cultural codes that dominated the texts produced by the most prominent Russian-language jihadist ideologues. It is precisely this factor that makes their language accessible and popular in the Russian-language environment, which consisted of people who were Soviet and post-Soviet in terms of their educational, cultural, and social experience.

At the same time, one cannot claim that this phenomenon is an outlier and has nothing in common with the jihadist struggle in other regions of the world. Therefore, it is important to note that the particular subject under consideration here can contribute a great deal to ongoing academic discussions on jihadism, religious extremism, and terrorism. To that end, I propose that we must begin with a description of the general context of those discussions.

\section{Jihad as a Global Phenomenon: A Historiographical Excursus}

In my view, it is currently possible to provisionally identify two basic lines of investigation into the ideology of the jihadist movement: (1) approaching it as a coherent global Islamic/Islamist ideology and movement and describing the universal religious characteristics that are inherent within it, and (2) concentrating on an analysis of the regional (ethnic or subcultural) ideological sources of jihadist movements. Both of these vectors share a focus on studying the religious component as the basis of jihad.

The key subject for understanding jihadism as a universal phenomenon in different regions of the world is the study of social types that contributed to the emergence of the ideology of jihadism. The French political scientist and Middle East expert Olivier Roy proposed calling such ideologues (not simply jihadists, but Islamists in general) "new intellectuals" and the "lumpenintelligentsia" (Roy 2001, 51). In his opinion, they did not hold religious or secular degrees, which determined their marginal position and encouraged them to create their own parallel institutions on the outskirts of cities (Roy 2001, 92). This social background apparently later enabled Roy to state that we are observing the "Islamization of radicalism," when social protests take 
on an Islamic form of expression. At the same time, it is worth noting that the latest research by British sociologists Diego Gambetta and Steffen Hertog provides grounds to state that there are a disproportionately high number of jihadists with university education in engineering, which partially refutes Roy's conclusions (Gambetta 2016).

Of course, the lack of systematic Islamic education among this type of extremist ideologues meant that they had poor knowledge of religious sources and did not have the status of alims (Muslim scholars). In the same vein, the British linguist Elisabeth Kendall used the example of Al-Qaeda ${ }^{5}$ to describe how jihadist ideologues compensate for the lack of religious authority by stating that they simply receive their fatwahs directly from Allah (Kendall 2016, 239).

The parallel institutions and networks created by those same intellectuals has proven effective enough to assert their authority and promote their ideas. For example, American researcher Mark Sageman's explanation of what he calls the "global Salafi jihad" primarily focuses on the social networks through which people set out on the road to jihadism (Sageman 2004). British sociologist Simon Cottee employed Sageman's data point that 66 percent of jihadists entered terrorist organizations along with their friends, while another 20 percent had jihadist relatives. In the same vein, Cottee attempted to examine the problem of jihadism from the perspective of criminology, that is, to study the phenomenon in the same way that one might study the formation of gangs or so-called delinquent subcultures. Cottee states that young jihadists independently create their own cells without any participation from Al-Qaeda and only then join that well-known organization (Cottee 2011, 730-51).

According to Cottee, the fact that these young jihadists live at the edges of European cities led them to be influenced by Western urban music traditions like rap and hip-hop (Cottee 2011, 732). Italian political scientist Lorenzo Vidino cites Cottee while describing how Islamic fundamentalism can be combined with the African American hip-hop aesthetic in European ghettos, leading to phenomena like young Muslims having photographs of both Tupac Shakur and bin Laden on their mobile phones or simultaneously using marijuana and viewing videos on jihad. Vidino provides numerous examples of Muslim groups and performers who use the style of hip-hop to promote armed jihad against "unbelievers" (Vidino 2007).

The perception of jihadist ideology and the jihadist movement as a global phenomenon, functioning as a kind of network, is characteristic

5. Banned in the Russian Federation by Decision of the Supreme Court of the Russian Federation dated 14 February 2003, No. KGPI 03 116, effective 4 March 2003. 
of many studies of the subject. For example, Australian international relations specialist Andrew Phillips compared the contemporary jihadist movement with the medieval Calvinists, describing what he calls modern Salafism as a sort of religious network like the ones that existed in Europe during the Reformation. Phillips referred to the work of German political scientist Herfried Münkler to argue that the terrorism practiced by jihadists is a new way of repudiating the state monopoly on violence (Phillips 2018, 257-80). A similar description of jihadism as a homogenous global phenomenon challenging the state monopoly on the use of violence can be found in the work of Israeli political scientist Barak Mendelsohn, who used the ideology of AlQaeda as an example to illustrate this thesis (Mendelsohn 2005, 61).

Some scholars have produced especially interesting studies that simultaneously point out the global nature of the jihadist movement and also address the existing regional agendas that might actually be even more relevant than its declared global pretensions. The work of British Arabic linguistics specialist Elisabeth Kendall is an interesting example of this approach that deserves detailed attention. She used the example of Al-Qaeda to analyze how jihadist propaganda exploits the Arabic poetic tradition. Kendall is interested not so much in the goals bin Laden was pursuing or his organization's ideology as in the propaganda instruments they used to promote the jihadist movement. Her analysis of numerous poetic works by bin Laden and his followers led to the conclusion that jihadist poetry has obvious pre-Islamic roots. Kendall points out that the poetry written by Al-Qaeda jihadists demonstrates that they are immersed in their local, tribal context and that their jihad was often provoked by internal problems (Kendall 2016, 230). In her view, the adoption of forms and styles from the pre-Islamic Arabic tradition occurs both unconsciously and quite consciousnessly, as was the case with bin Laden. In any case, the jihadists do not regard the fact that their poetry draws on pre-Islamic sources as a problem; on the contrary, they are prepared to use that poetry to establish their own authority, just as they use the Quran (Kendall 2016, 229). Kendall states that they adopted this device because it was extremely important to them to demonstrate that they are associated with Arab mass culture rather than a counterculture or subculture (Kendall 2016, 240).

This observation is important in relation to the aforementioned work by Simon Cottee, in which he suggested that the jihadist movement should be regarded as a subculture phenomenon, consisting of marginal people striving to place themselves in opposition to the dominant order. Kendall's work, however, demonstrates that there 
are grounds to doubt that the jihadists viewed themselves as a counterculture, or at least we must recognize that there are different forms of jihadism and that any statements about universal characteristics of global jihadism must come with caveats.

In any case, according to Kendall, local cultural material plays a much more important role than has been acknowledged (Kendall 2016, 239). She argues that cultural heritage has the potential to be a powerful propaganda tool when it is reconstructed to have significance that is useful to the jihadists, and therefore even non-Islamic material can be a component of jihadist propaganda (Kendall 2016, 242).

Kendall noted that since bin Laden had no religious authority, this poetic cultural heritage proved to be, in Pierre Bourdieu's terms, cultural capital, which enabled him to acquire more power (Kendall 2016, 238). According to this British Middle East expert, bin Laden and his allies used poetry to make their actions, which appeared illogical and unlawful from an Islamic perspective, seem logical and lawful. They also found images of warriors and their triumphs in this tribal pre-Islamic poetry that fully correspond to the contemporary image of the martyr (Kendall 2016, 237). Furthermore, as has been noted, Al-Qaeda ideologues' claims that they received their instructions directly from Allah were actually a consequence of their lack of religious authority.

Thus, on the one hand we see a picture of the jihadist movement as a counterculture phenomenon, as described by Simon Cottee, Lorenzo Vidino, and other researchers, while Elisabeth Kendall, on the other hand, essentially asserts the opposite, that Al-Qaeda jihadists avoided the counterculture position and strove to demonstrate that they were an authentic part of Arabic culture. In other words, there are clear differences between the strategies used by jihadists in the Arab Middle East and Europe use to promote their ideologies. In this regard, according to Elisabeth Kendall, literary analysis can be used to shed light on the contemporary political landscape (Kendall 2016, 230). Kendall used the terminology of French poststructuralist philosopher Jean-François Lyotard to claim that jihadist ideologues from Al-Qaeda have created a kind of new grand récit, or "grand narrative" (Kendall 2016, 227).

In my opinion, the fact that some Muslims in Europe may be motivated to pursue jihad by "non-Islamic" hip-hop, while those in Arab countries may be motivated to do the same by ancient pre-Islamic poetry, means that this grand utopian narrative of the creation of an Islamic state as a result of a "jihad against the infidels" is formed from whatever material is ready to hand and can yield results in a specific set of circumstances. In this instance, it is not important whether jihadists 
make this case consciously or unconsciously. In poststructuralist terms, this picture is like a bricolage randomly assembled from diverse pieces, in which the terms jihad and caliphate 6 play the role of brands that can represent extremely varied agendas. For some, that might be the countercultural revolt of the migrant, guided by his surroundings, and for others it might be just the opposite, an effort to conform to the dominant cultural tradition in order to unite against the new colonialism. The strategies and motivations can be as different as the ideological content of their messages; the same applies to the forms in which they express those ideas. The one factor that remains unchanged is that jihad (understood to mean armed opposition to the "infidels" and the Western world) takes priority in their struggle. Since there were quite obviously a large number of factors involved in the formation of jihadism, a full understanding of the phenomenon requires a comprehensive analysis of all of its manifestations in different regions of the world.

\section{Jihad in the Northern Caucasus: Regional or Global? A Brief History of the Question}

The study of regional examples of the jihadist movement also has a very rich and diverse historiography. The main trend among serious studies of this problem is an acknowledgement of the internal causes behind the emergence of armed struggle in the name of jihad (see Bonnefoy 2012). At the same time, when researchers discuss the ideological element of the movement, they describe it as part of a global jihadist ideology.

The same applies to the Northern Caucasus. There are a significant number of scholarly works dedicated to this region; they analyze a wide variety of aspects of jihadism, including the ideological dimension of the movement. As is the case for other regions of the world, the dominant trend here is also one of studying the problem as part of a global jihadism, that is, of identifying the ideological and organizational connections with extremist groups from the Middle East. For example, this type might include the work of British military research specialist Domitilla Sagramoso, who explained the radicalization of jihadist fighters and extremists in the Northern Caucasus as the result of the influence of global Salafist jihadism, which penetrated the area through students who had studied in Arab countries (Sagramoso

6. This term is derived from an Arabic word meaning "inheritance." The Muslim state created by the Prophet Muhammad in the 7 th century was called the Caliphate. This word is now used to refer to a supranational theocratic Islamic state. 
2012, 567). British political scientist Roland Dannreuther advanced a similar argument, writing that the Islamization of the insurrectionist movement in the Northern Caucasus is associated with its integration into global, transnational jihad (Dannreuther 2010, 109-26). The Australian researchers Ben Rich and Dara Conduit reached essentially the same conclusions, writing that the armed Chechen paramilitary opposition proved subject to foreign Salafist framing (Rich 2015). At the same time, both Domitilla Sagramoso and Roland Dannreuther note that the movement of North Caucasian fighters was initially caused by local social and political problems.

The Russian-American Middle East expert Alexander Knysh argued in his study of the ideology of the jihadist organization known as the "Caucasian Emirate" that there is nothing original to be found in the ideas of the North Caucasian jihadists. In his opinion, analogous ideas of Muslim opposition to the enemies of the Ummah can be traced in the works of the Salafist and fundamentalist authors Sayyid Qutb (1906-1966) and Abul A'la Maududi (1903-1979). Furthermore, Knysh points out that contemporary jihadists from the Northern Caucasus actively use Arabic and Islamic terminology, which also makes them closer to foreign jihadists.

This line of research treating Northern Caucasian jihadism as part of a worldwide jihadist movement continues in a collection edited by Stephen Blank and published by the American War College, which focused on studying the international factors that influenced the formation of the "Caucasian Emirate." The authors primarily emphasize how typical the ideology of that organization was of the international Salafist/jihadist movement.

One specific chapter of this book is especially relevant for my research.$^{8}$ The author of this chapter, American scholar Gordon Hahn, writes that the ideology of the "Caucasian Emirate" is precisely the same as the Salafist ideology preached by Al-Qaeda and other groups in the global jihadist revolutionary alliance (Blank 2012, 4). Hahn thinks that the jihadist ideology itself is a major driving force for jihad in the region (Blank 2012, 27-28).

While the importance of studying the international connections of jihadists from the Northern Caucasus cannot be denied, I believe that

7. See Knysh. More specifically, Knysh studied the main Internet portal used by jihadists in the Northern Caucasus, Kavkazcenter.com, as well as speeches by several ideologues of this movement: Dokka Umarov, Anzor Astemirov, and Movladi Udugov.

8. It is entitled "The Caucasus Emirate Jihadists: The Security and Strategic Implications." 
concentrating exclusively on that question makes it impossible to understand this phenomenon in its totality, to explain the reasons for its popularity in the post-Soviet space, and to see what makes it unique and distinct. It is, however, the study of the internal factors behind the emergence of the jihadist movement and its ideology in the Northern Caucasus that, in my opinion, has proven undervalued in the existing historiography on this question. Nonetheless, a small corpus of research serves as an excellent illustration of how significant these internal roots truly are.

Several works by Irina Starodubrovskaia offer a close analysis of the internal social and economic reasons for the formation of the jihadist movement in the Northern Caucasus (Starodubrovskaia and Sokolov 2013, 277). There have also been other studies on the internal factors that affected the formation of the jihadist ideology in the Northern Caucasus. For example, Michael Kemper pointed out that the Russian journalistic tradition and the songs of Soviet soldiers in the Second World War obviously influenced the jihadist discourse employed by propagandists of the "Caucasian Emirate" (Kemper 2012, 273). Kemper also noted that the range of Islamic terms that those propagandists actively used was not actually very broad, and that the Islamic phraseology they employed was rather simple. In other words, their jihadist language was not grounded in deep Islamic education (Kemper 2012, 293).

Another author who devoted significant attention to the fact that the jihadist discourse in the Northern Caucasus has a Soviet-Russian intellectual layer, in addition to the Arabic-Islamic one, was the American historian Dmitry Shlapentokh. In his opinion, researchers have yet to give the influence of Russian cultural and political traditions on jihadist ideology the attention it merits (Shlapentokh 2012, 276). According to Shlapentokh, the influence of Eurasianist ideas, Russian Marxism, and Russian messianism can be felt quite keenly in the ideology of the jihadists in the Northern Caucasus during the first stage of the Russian-Chechen conflict. He does, however, contend that the jihadists in Russia shifted to the style of Islamist ideology during the second stage.

Vladimir Bobrovnikov also identified clear Soviet and post-Soviet themes in the propagandistic ideology of Northern Caucasian jihadists (Bobrovnikov 2011, 291-301). More specifically, he pointed out the fact that the Islamic polemical genre of documentary films in the Northern Caucasus was influenced not only by the Islamic missionary tradition, but also to a significant degree by Soviet propaganda from the Cold War period, including anti-Western and anti-Semitic elements. Furthermore, Bobrovnikov argues that the influence of (post-) 
Soviet pop culture is also quite apparent, especially in the production of Internet videos on shahids. ${ }^{9}$

Czech researchers Emil Souleimanov and Ondrej Ditrych pointed out analogous internal roots for jihadism in the Northern Caucasus in their work on blood feuds as a factor in the region (Souleimanov 2008, 1199-1222). Similarly, Russian ethnographer Akhmet Yarlykapov denied that militants in the Northern Caucasus were fighting to establish a "world caliphate" (Yarlykapov 2014, 215).

Valery Tishkov's work on the fact that "in Chechnya, motifs of Chechen greatness and Islamic messianism coexisted with the expansionist idea of liberating the Caucasus from the imperial domination of Russia and creating a unified 'house of the Caucasus' or 'Caucasian confederation," has particular significance for this study. According to Tishkov, the primary ideologues of such projects were Zelimkhan Yandarbiev and Movladi Udugov, as well as a relatively sizable contingent of writers, political journalists, and historians who emerged in Chechnya (Tishkov 2001, 466). Udugov and Yandarbiev created quite a large body of texts justifying and conceptualizing their jihadists struggle, which means that they are also relevant.

While Valery Tishkov is absolutely right, it must be noted that this expansionist messianism was clearly "Soviet" in nature. In fact, this phenomenon cannot even be regarded as fully unconscious, since the works of both of these ideologues drew clear parallels between their own views and the policies of the Soviet Union.

\section{Zelimkhan Yandarbiev: The USSR, the West, and the Is- lamic World}

Zelimkhan Yandarbiev, a former member of the Communist Party of the Soviet Union and the Soviet Writers' Union, an alumnus of the Advanced Literary Courses at the Maxim Gorky Literature Institute and the philology department of the Chechen-Ingush State University, devoted significant attention to the formation of the concepts behind political and military struggle (Yandarbiev 2016). Therefore, he left behind a certain number of rather interesting works, which occupy a prominent place in the body of texts by Russian-language jihadists, and can be used to develop a sense of the intellectual space they occupied.

9. The term "shahid" comes from an Arabic word that is translated as "witness" and used not only to refer to, for example, a witness at a trial, but also in the sense of "a martyr for the faith" who died in battle in the name of the Almighty. 
Specifically, in 1996, Zelimkhan Yandarbiev published a book in Lviv entitled Chechnya: The Battle for Freedom. This book was a collection of his works, written both in the early and mid-1990s. It began with a poem by Alvadi Shaikhiev (born 1947), a Chechen poet who was also a graduate of the Advanced Literary Courses, with the characteristic title "In Chechnya There Is a Jihad."

Yandarbiev describes his own struggle using Muslim/jihadist terminology. Furthermore, the same collection included his material from the early 1990s, in which there was no obvious "appeal to Islam." This material constitutes evidence that he was already searching for supranational forms of unification that could bring the entire Caucasus together in a struggle against Russian power in the early $1990 \mathrm{os}$.

For example, he developed the concept of the "Caucasian character" (literally "Caucasianness") - a certain common spirit of freedom and independence that he claimed was characteristic of that region's people (Yandarbiev 1996, 100). In the chapter entitled "The Caucasian Character," written in 1990, Yandarbiev refers to Hegel's Phenomenology of Spirit to demonstrate the existence of a unique "Caucasian race." Furthermore, according to Yandarbiev, the Caucasian character is a kind of national identity that unites all of the people of the Caucasus, including even the Russian Cossacks.

Moscow, however, supposedly provokes ethnic and religious conflicts between these peoples in order to colonize them. Therefore, according to Yandarbiev, the peoples of the Caucasus need political unity against Russia's imperialist policies. It is important to note that Yandarbiev also includes the Russian Cossacks in this project, thereby adding a certain messianic enthusiasm to his message, which serves to elevate it above interethnic problems. It is quite clear that Yandarbiev was, in a sense, repurposing the trappings of Soviet ideology in this book. His rhetoric recalls the style of Soviet propaganda, but redirected against Moscow itself; in effect, he claims that these peoples can only truly develop within the framework of a larger supranational political structure (in Soviet terms, that would be the USSR), while external imperial forces (in the language of Soviet propaganda, that would be the West) are attempting to prevent that from happening.

In order to prove that his project of supranational unification for the peoples of the Caucasus was relevant, Yandarbiev had to persuade his readers that Soviet ethnic policy had failed. For example, in his chapter "Essence and Elements of National Unity," he criticizes Soviet ethnic policy as not being in the interests of the Soviet peoples. 
Yandarbiev claims that it was precisely this idea that Soviet dissident writer Aleksandr Solzhenitsyn (1918-2008) meant when he wrote in his novel The Gulag Archipelago that Soviet power was never actually accepted by the spirit of the people. According to Yandarbiev, the deportation of Chechens to Central Asia, as well as the painful methods used to establish communist control in the Northern Caucasus in the 1920s-30s, led Chechens to develop a clear distinction between "ours" and "not ours [theirs]," that is, the government, which they perceived as belonging to no one.

Solzhenitsyn was not the only author that Yandarbiev referred to who became relevant in the post-Soviet period. In particular, he refers to the opinions of Abdurakhman Avtorkhanov (1908-1997), an American political scientist of Chechen ancestry and a tireless critic of Soviet policy. Yandarbiev cited him while substantiating his thesis that the branches of the Communist Party of the Soviet Union in the national republics of the USSR did not fight for the rights and interests of the peoples they formally represented. He also cites Italian journalist and socialist historian Giuseppe Boffa (1923-1998), also regarded as an anti-Soviet author in the USSR, whose most famous book, The History of the Soviet Union, could only be published with the onset of perestroika. Citing that book, Yandarbiev states that the policy of the Soviet authorities led the country to a political and economic crisis. All of these factors together, in his opinion, impelled the peoples of the USSR toward active participation in the country's political life.

As can be seen from the events that followed in the Northern Caucasus in the 1990s, Zelimkhan Yandarbiev's search for a new political project led him to support the so-called Islamic turn taken by the ideology of those who fought on behalf of the self-proclaimed Republic of Ichkeria in the second half of the decade, and the promotion of a project to create a new political entity in the region - an Islamic state. In 2000, Yandarbiev even published a book entitled Jihad and the Problems of the Contemporary World, in which he argues in support of the need for jihad and lays out his understanding of its place in the context of modernity.

Only a portion of this text appears to be available at time of writing, ${ }^{10}$ but it is enough to show that Yandarbiev discusses a bipolar world, where one pole is the Christian world, with its inter-

10. Yandarbiev's Facebook page, which was later deleted, included several portions of his book, which I have preserved in Word format for my own archives. 
ests defended by the UN, NATO, other international organizations, and the governments of the Western countries, and the other is the Muslim world, which, in his view, lacks any such clear defenders. According to his position, the USSR, as the leader of the socialist camp, once constituted the second pole, but after its collapse, the Muslim world played that role. Yandarbiev asserts that the Christian countries saw the Islamic world as their new enemy, which had great political and economic potential. He contended that representatives of other religions who were politically, economically, and technologically dependent on the Western world found themselves at the same pole as the Islamic world. In his opinion, they would serve as a bargaining chip for the Western world in its struggle with Islam and would be destroyed if the Islamic world fell. Therefore, according to Yandarbiev, the specific potential of the Islamic world makes it the leader of this second pole at which the countries that had been wronged by the West found themselves. The style of Soviet propaganda, which declared the USSR the leader of the worldwide anticolonial movement, is easily recognizable in this rhetoric, but in the language of Yandarbiev, the project he himself was supporting and formulating, that is, the creation of an Islamic state, took the place of the USSR. In that context, he regarded the Chechens as the vanguard of the world Islamic community. As Yandarbiev wrote, the messianic role of protecting the weak from "the strong of this world," required following the path of jihad, including "the jihad in Chechnya (Ichkeria).”

For Yandarbiev, jihad a priori meant a military conflict, which should not only yield a victory for Muslims, but also bring happiness to all of humanity. Certain eschatological elements of the texts notwithstanding, Yandarbiev was primarily discussing jihad in a sociopolitical rather than theological register.

Yandarbiev practically never uses specifically Islamic terminology or cites Muslim sources when discussing jihad. He builds his primary argument in favor of the need for jihad on the idea of justice, which was violated by the Western powers. This is also related to his rhetoric, which uses the style of Soviet propaganda. In this fashion, he attempts to grant the conflict in Chechnya a high mission as one of the stages of a struggle for the future of humanity. This framing of a bipolar world in which the Islamic world has taken the place of the USSR, as well as the reuse of the logic and arguments of Soviet propaganda are entirely explicable as products of Yandarbiev's Soviet professional and educational experience. 


\section{Movladi Udugov: The Bolsheviks, Karl Marx, and the Quran}

Movladi Udugov is another example of the same phenomenon. Unlike Yandarbiev, during the Soviet years he managed to become a candidate for membership in the Communist Party of the Soviet Union but was not accepted because he expressed nationalistic views ("Udugov obvinil" 2006). According to some reports, in addition to being trained at the economics department of Chechen-Ingush State University, he also spent some time at the journalism department of Leningrad State University and worked as a journalist for the Chechen newspaper Komsomolskoe plemia [Komsomol banner] (Pylev 1999; "Udugov obvinil" 2006). In the 1990s, Udugov essentially became one of the main ideologues for the fighters who were active in Chechnya, and in the 2000s, he was one of the ideologues of the jihadists of the "Caucasus Emirate." Udugov was referred to as the "Chechen Goebbels" in the 1990s, since he waged an information war with Moscow as Dudaev's press secretary and then as the minister of information of Ichkeria. He then became one of the figures who supported the so-called Islamist turn in the ideology of the fighters in the Northern Caucasus and created the well-known website Kavkazcenter.com, which became the main informational portal for the "Caucasian Emirate" and Russian-language jihadist propaganda in general.

Like Zelimkhan Yandarbiev, Movladi Udugov declared that his struggle would not be limited to the Northern Caucasus; his ambitions became broader, extending to the rest of Russia. In one of his interviews, he refers to regions such as Tatarstan and Bashkortostan, which have traditionally been home to many Muslims, as well as Buryatia, Tyumen, Vladivostok, and Moscow, which he claimed were home to many Russians who had accepted Islam and sworn allegiance to the leader of the "Caucasian Emirate," Dokka Umarov. Udugov also calls on other Russians to follow their example since he holds that Sharia should serve as an alternate way of seeking a special "Russian path" (Udugov 2008). In other words, he does not demonize the Russian people as an enemy, but instead includes them discursively in what he believes should be the world's dominant project.

As will become apparent, Movladi Udugov's rhetoric could more accurately be called expansionist than separatist. Udugov proposes an alternative path to greatness for Russia, one within the framework of a larger community, that is, the world Ummah. In this regard, Udugov might be counted as part of the circle of Russian intellectuals, like monarchists or Eurasianists, who sought new great ideological pro- 
jects that might be capable of taking the place of the former communist narrative that disappeared after the fall of the Soviet Union.

In this context, it is striking that Udugov's descriptions of ways to fight for Shariah refer to historical parallels drawn from the Soviet past, which were intended to serve as examples for contemporary Muslims. For example, in 2005 he and his "Islamic Center for Strategic Research" published a large text entitled "Thoughts of a Mujahid," in which he stated that Muslims must follow the example of the Bolsheviks in developing a strategy for their struggle for power (Kavkazcenter 2005).

Udugov argued that communism and the Muslim religion had obvious shared principles. More specifically, he held that the ideas of self-sacrifice and social justice played central roles in both Islam and Bolshevik ideology (Kavkazcenter 2006a). Furthermore, he concluded that the methods the Bolsheviks used to organize their state were similar to Muslim ones. For example, he compared the functioning of the Bolshevik "Soviets [Workers' Councils]" as the foundation for a new Soviet form of statehood with shura (from an Arabic word that also translates as "council"), the Islamic principle of consultation as the foundation for Islamic governance. Udugov sees a whole range of obviously similar stories in the histories of Islam and Bolshevism. He argues that the Communists established their power using the technology of Shariah and the historical experience of Islam.

Udugov wrote that the Bolsheviks, like the Muslims, had sacred scripture: Karl Marx's Capital. Furthermore, Communism, like Islam, had the idea of a holy war for the faith, which, also like Islam, enabled it to spread halfway around the world in a single generation. Udugov pointed out that the Bolsheviks also had to undergo a process of relocation - from the Russian Empire to Europe, in their case. The reader is apparently meant to draw a parallel with the hegira, the relocation of the Prophet Muhammad and his companions from Mecca to Medina. Udugov cites Soviet People's Commissar of Enlightenment Anatoly Lunacharsky to prove that the Bolsheviks viewed their ideology as nearly religious in nature.

Thus, Udugov states that the Bolsheviks simply repurposed the Islamic experience, which demonstrated the need for contemporary Muslims to remember their history. For example, he held that Muslims, like the Bolsheviks in their time, should not participate in democratic systems, which are alien to them. Udugov wrote about the fact that Bolshevik authority was only able to endure for seventy years; since, however, the world needs a force to oppose the West, he was proposing a new project, which was meant to be a de facto replacement for the USSR, that is, an Islamic Caliphate. 
In his article "Thoughts of a Mujahid," Udugov refers to Marx, Lunacharsky, and Solzhenitsyn, but does not cite any Muslim author. It must be noted that citations of Muslim authorities were also quite rare in his other texts. Furthermore, Udugov's language was not rich in Arabic or specifically Islamic terminology. Like many post-Soviet authors, he criticized Western political values and institutions, proposing that Russia follow its own special path.

The example of Movladi Udugov is largely representative of postSoviet jihadists. This is particularly true of jihadists who took center stage in the politics of the Northern Caucasus during the 1990s, and who were Soviet people, socialized in the late Soviet period. Like Udugov, most of them did not receive Muslim education abroad, and, as a rule, were not Arabic speakers. At the same time, they had substantial experience being socialized in the Soviet Union, including a Soviet education and sometimes a fully successful career, and as a consequence, Soviet intellectual baggage. This experience left a noticeable imprint on why and how they formulated their post-Soviet ideology and their arguments for jihad.

The collapse of the USSR and the fall of its communist ideology did not simply create an ideological vacuum; it also kicked a whole generation to the curb of history, after they had attached their hopes for the future to that vast country. In essence, it was these people who became the leaders of the new Ichkeria. It is possible that many of them, like Dzhokhar Dudaev, Aslan Maskhadov, Shamil Basaev, and Dokka Umarov, who had lived and built their careers outside of Chechnya until the early 1990s, saw returning there as an act of ethnic patriotism, but in practice it was an attempt to create a new grand Islamic project as a substitute for the now-collapsed USSR.

\section{Iasin Rasulov, Said Buriatskii, and Anzor Astemirov: The Legend of the Mankurts, Passionarity, and the Arab Lexicon}

In the post-Soviet period, many representatives of the Soviet and, soon after, Russian humanities intelligentsia from the North Caucasus, joined the ranks of the militants in the Northern Caucasus and strove to justify the jihadist struggle there. They used historical arguments that were meant to vindicate their struggle. This led to the formation of their own mythology, based on historical material drawn from both the local context and the entire Soviet Union/Russian Federation. The jihadist ideologues were striving to simultaneously deconstruct ethnic 
and Soviet historical myths and create their own, sometimes by constructing continuity with the region's past.

To some extent, these jihadists could be regarded as participants in the so-called memory wars ${ }^{11}$ that were characteristic of the post-Soviet intellectual space (Shnirel'man 2003). For example, some criticized various nationalist narratives ${ }^{12}$ and interpreted the region's past in their own way, as did Timur Mutsuraev, who called himself "the bard of jihad," and who referred to the history of the Chechen people of the Northern Caucasus in his work (Mutsuraev 1998). The literary legacy left by the jihadist intellectuals of the Northern Caucasus is, of course, a rich source for research purposes. ${ }^{13}$

Their participation in the wars of memory was accompanied by the device of providing historical justifications for the rightness of their cause, which was typical for the post-Soviet period. For example, in 2005, Iasin Rasulov, a former graduate student at the Dagestan Academy of Sciences and an ideologue of the Dagestani jihadist group Sharia (which became part of the "Caucasian Emirate" in 2007) published a long programmatic text entitled "Jihad in the North Caucasus: Supporters and Detractors," which was used to justify militant jihadist activity via manipulation of historical fact and appeals to historical memory from a jihadist position (Rasulov 2016). Rasulov's text is dedicated to the history of jihad in the Northern Caucasus from the 18th to early 21st century. It was published immediately after he went underground, and was his first and only work, in which he attempted to somehow justify, explicate, and conceptualize the jihadist struggle in the North Caucasus.

11. For example, Said Buriatskii's article, "The Hero of Truth and Falsehood" [Geroi istiny i lzhi] strives to prove the falsehood of Buryat, Karelian, and even American myths. Furthermore, he strives to debunk famous Soviet mythologems such as the stories of Pavlik Morozov, Zoia Kosmodemianskaia, and Alexander Matrosov.

12. Iasin Rasulov, an Avar, criticized the muftiate of Dagestan for adherence to the trends represented by a sheikh identified exclusively with that ethnicity, Said Afandi al-Chirkawi (Chirkeiskii) (1937-2012) and intolerance of sheikhs of other ethnicities. Anzor Astemirov, a Kabardian, criticized the leadership of Kabardino-Balkaria for the creation of ethnic myths. Movladi Udugov, a Chechen, criticized the Chechen nationalists who had left for the West and had spoken out against the jihadist struggle waged by militants in the North Caucasus.

13. One such example is the 1998 book Chechens in the Russo-Caucasian War [Chechentsy v russko-kavkazskoi voine] by Field Commander Dalhan Hozhaev (1961-200o), who was a graduate of the history department of Chechen-Ingush State University and who spent the Soviet years working in a museum dedicated to the region's history. His book collected the biographies of famous Chechens who supported the Caucasus-wide uprising of Imam Shamil during the Caucasian War of 1817-1864. Hozhaev described this uprising in the terms of a holy Islamic war - gazavat. 
The conceptual framework for this text was, rather unexpectedly, provided by the views of famous Soviet writer Chinghiz Aitmatov (1928-2008) on the historical process. Early in the book, Rasulov includes a large excerpt from his novel, The Day Lasts More than a Hundred Years, specifically the "legend of the mankurts."14 This quotation accounts for almost a third of Rasulov's preface. Aitmatov's legend of the mankurts becomes a kind of frame for Rasulov, serving to explain the necessity for his own text as a solution to the lack of historical memory. He writes that, in his opinion, a person cannot permit himself to be transformed into a mankurt and is obligated to know his "true past." Rasulov claims that it is only through "historical memory" that one can understand the truth of events in the contemporary Caucasus. For Rasulov, historical excursus is only necessary to understand modernity, or, in other words, to vindicate both his own actions and those of like-minded individuals in the "Shariah" movement.

Rasulov used terms like "mankurt," "historical memory," and "historical amnesia" several times in his text. This naturally raises a question: why did a Soviet writer prove so necessary to one of the ideologues of jihadism in the Northern Caucasus? The key fact is that Aitmatov was regarded not only as a classic Soviet author, but also as an important name for post-Soviet culture. During that period, his term "mankurt" became very popular among Russian writers, historians, and ideologues of many different schools. Svetlana Boym was actually referring to this phenomenon when she wrote that Soviet intellectuals of the Glasnost period were fighting for the right not to be mankurts (Boym 2002, 294). Victor Shnirelman also notes that Chinghiz Aitmatov's figure of the mankurt achieved extraordinary popularity in late Soviet and post-Soviet folklore (the struggle with the mankurt phenomenon) (Shnirel'man 2006, 14; see also Coombs 2011, 47-64 and Atkin 1993, 151-58). Shnirelman indicates that this figure is fully analogous to the ideas of Lev Gumilev (1912-1992), and specifically his images of "chimeras" and "mongrels," people who have completely lost their ancestors' attainments. Accordingly, there are grounds to claim that the metaphorical image of the mankurt was a post-Soviet cultural phenomenon and a marker of post-Soviet language.

14. According to the legend created by Chinghiz Aitmatov, the mankurts were slaves who had forgotten their past. 
Returning to Rasulov's work, it is worth noting that the primary thesis of his text is that all of the uprisings of the Caucasian peoples against Russian power from the 18th to 21st centuries were links in a single chain, an anti-colonial movement based on the ideology of Salafism. In his view, such legendary figures for the North Caucasus as Imam Shamil (1797-1871), Sheikh Mansur (1760-1794), and Ghazi Muhammad (1795-1832), were Salafists, rather than Sufis, as the official view would have it. Rasulov created a heroicized image of the North Caucasian rebels. At the conclusion of his work, Rasulov cites Chinghiz Aitmatov once again, in order to convince the reader of the importance of avoiding failures of historical memory.

Another key feature of Rasulov's text is the fact that it was created according to the rules of the Russian academic tradition: footnotes, introduction and conclusion, and a clear formulation of the question under study and the goal of the work. Rasulov does not rely on Shariahbased arguments to justify jihad, and instead states that jihad - and specifically Salafist jihad - is a normal, historically grounded way for the peoples of the North Caucasus to interact with Russia.

Developing this theme, Rasulov refers to such famous Russian scholars of the eastern world (Orientalists) as Leonid Sukianen, Vladimir Bobrovnikov, and Alexander Malashenko. He also quotes Pushkin, the Russian Emperor Nicholas I, Dagestani political figures from the past, and even contemporary Russian-Israeli writer and journalist Israel Shamir. Although Rasulov does refer to the Quran several times, Islamic scholars and thinkers are not included among the authorities he draws upon to build his argument. Rasulov is an interesting example of the use of academic style to argue in support of the jihadist movement in the contemporary North Caucasus.

Another of the leaders and ideologues of the terrorist group known as the Caucasian Emirate, Said Buriatskii, published a programmatic article entitled "Istishhad: Between Truth and Falsehood" in 2009. ${ }^{15}$ This was his first and only text, which was exclusively dedicated to his interpretation of the causes of jihadism and people's readiness to die while walking that path (istishhad) ${ }^{16}$ with extensive text along a broad historical timeline, from the creation of the Caliphate to the contemporary jihadist movement in the Northern Caucasus.

Buriatskii, who had some degree of (incomplete) Islamic education, since he attended a Russian madrassa in Buguruslan and briefly studied

15. For more on Said Buriatskii and Lev Gumilev, see Garaev 2017.

16. Istishhad, which comes from the word shahid, refers to the act of dying as a martyr. 
Arabic in Egypt, does not appear as a Muslim scholar in this text. At the very beginning of the text, he indicates that he will not offer Shariah-based justifications for the jihadist movement. Furthermore, like other jihadists, such as Movladi Udugov, Zelimkhan Yandarbiev, and Iasin Rasulov, Buriatskii does not mention Muslim authors at all in his argument for jihad.

In order to explain the phenomena of istishhad and jihad, he refers to the theory of passionarity, developed by the aforementioned Lev Gumilev, whom the author states he read as early as grade school. For Buriatskii, Gumilev's theory offered the highly attractive category of "the quality of sacrifice" or "the quality of self-sacrifice"; hence, his paraphrase of Gumilev's formulation states that people's ability to sacrifice themselves is the point of peak development for any civilization's passionarity.

By making this category central to his explanatory model, Buriatskii, in my view, is attempting to change the attitude of Russian society toward the phenomenon of suicide attackers ("shahids") from the negative image of a terrorist fanatic to the more noble image of a martyr. Furthermore, it speaks to Buriatskii's concept of the audience he was addressing. It will become apparent that he was striving to present himself to them not only as a Muslim ideologue, but also as a thinker with a Russian intellectual foundation.

As we will see, though both Said Buriatskii and Iasin Rasulov were representatives of the generation of jihadists that followed Yandarbiev and Udugov, they remained quite close to their ideological forebears. The main difference was that they had some degree of Islamic knowledge and biographies that were unconnected with the First and Second Chechen Wars. It must be noted, however, that their lexicon and choice of authoritative sources to draw upon when arguing in support of jihad reveals them, like Udugov and Yandarbiev, as Russian intellectuals in the post-Soviet mold who use language that is familiar and comprehensible for Russian-speaking readers.

One cannot, of course, state that all of the jihadist ideologues of that generation avoided using extensive Muslim/Arabic terminology and consistent Islamic arguments. For example, one exception to this type was Anzor Astemirov, who was practically the only one of the best-known leaders of the jihadist movements in the 1990s-2000s to receive a systematic Muslim education in an Arab country. The language used by Astemirov, who spent several years in the 1990s studying in Saudi Arabia and had the status of a Sharia judge in the Caucasian Emirate in the 2000s, was most markedly influenced by Arabic. Furthermore, he often cited Muslim authors, including so-called Salafists, 
like Ibn Taymiyyah (1263-1328) ${ }^{17}$ and al-Albani (1914-1999). ${ }^{18}$ More specifically, this can be seen in his main work justifying jihad, entitled "Jihad against Apostates" [Dzhikhad protiv verootstupnikov], which was published in 2007 (Sayfullah 2007). This instance, however, is best described as the exception that proves the rule. Apparently, the use of Arabic and Muslim terminology had symbolic significance for Anzor Astemirov, a Sharia judge, and was intended to legitimize his special religious status. Nonetheless, Astemirov, like Buriatskii, Rasulov, and other jihadist ideologues, obviously understood what kind of audience they were addressing. Therefore, despite the fact that the aforementioned work often includes Arabic/Islamic terms, each of them is followed by a Russian translation in parentheses. Furthermore, the reverse process also occurred, with Russian terms used in the text being followed by Arabic translations, also in parentheses. ${ }^{19}$

As such, Astemirov's texts might be called a unique manual on the translation of Islamic terminology into Russian and vice versa. It is obvious that Astemirov himself understood that neither the majority of Muslim youth in the North Caucasus, nor the Russian-language audience beyond the Islamic space would have understood text rich in Arabic/Islamic terminology. It was this that led to the constant linguistic switch code within a single text.

The intermediary position of Astemirov's language may be a sign of a gradual transition of post-Soviet jihadist language to more globalized variants that have lost the Soviet roots and post-Soviet stylistics, forms, and content that were characteristic for both Astemirov's predecessors and his intellectual allies in the Caucasian Emirate. These variants drew closer to the style of ISIS's contemporary propaganda work.

The examples of the aforementioned Northern Caucasian ideologues are quite revealing; they spoke Russian in the fullest sense of the word, that is, on the level of symbols, terms, and cultural codes that were recognizable to Russian-language readers. Essentially, the available evidence suggests that these ideologues were referring to those authors who had either acquired particular popularity in the Russian-language environ-

17. A Muslim theologian and jurist of the Hanbali legal school who is famous as a critic of innovation (bid'ah) in Islam. Today, he is typically considered a forerunner of so-called Salafism.

18. A contemporary Islamic theological and hadith scholar who is regarded as one of the most authoritative figures in the so-called Salafist current of Islam.

19. Another example of work by Astemirov is his text "Amir Sayfullah's Answers to Muslims' Questions," see Kavkazcenter 2006b. 
ment in the late or post-Soviet period, or who were an important part of the official Soviet narrative. The ideas and terminology of authors like Chinghiz Aitmatov and Lev Gumilev, Aleksandr Solzhenitsyn and Anatoly Lunacharsky, do more than permeate the jihadist discourse. To some extent, the Russian jihadist discourse was formed and even engendered by the ideas and legacy of these authors. In this regard, the Soviet cultural field (both dissident and officially sanctioned) and Russian radicalism proved sufficiently broad to find a place for Islamic radicalism.

Thus, it is no coincidence that jihadist ideologues almost always avoid debates on Sharia or theology when discussing jihad. The works of all of these authors are not simply arguments and justifications for jihad. Rather, they are investigating it, attempting to trace its genealogy. Stylistically, it is at times shaped by Soviet/Russian academic tradition, rather than any religious tradition.

There is not actually anything terribly Islamic in the Russian-language jihadist discourse of the period. The problems that the jihadist authors under consideration here touch upon and the forms in which they express their ideas, and, as a matter of fact, many of those ideas themselves, along with the terminology and the authorities they cite, are primarily non-Muslim in origin. Russian-language jihadism can be seen as a phenomenon with palpable Soviet and post-Soviet roots and fits rather well into the ideological/intellectual and cultural trends of post-Soviet Russia.

In my view, this study demonstrates that this phenomenon cannot be exclusively identified with regional or global jihadism. The example of the Northern Caucasus shows that this dichotomy is not useful. In this case, in addition to the regional ethnic variable and the global Islamic one, a third variable emerges, the (post-)Soviet one, that is, the interconnected Soviet intellectual heritage and post-Soviet political agenda. It is this third variable that was largely responsible for shaping the jihadist discourse, affecting its language, content, and style, and thereby constituting yet another example of post-Soviet radicalism, which can be placed alongside Eurasianism, monarchism, and the various forms of Russian imperial nationalism.

In Elisabeth Kendall's terms, positioning the problem of jihadism between regional (ethnic or subcultural) projects and the global Islamic project represents a failure to take into account the potential influence of other universalist metanarratives (the Soviet one, in this case) on jihadist ideologues. I would suggest that post-Soviet people, accustomed to thinking in terms of the categories of metanarratives, responded to the failure of one of them by turning to jihad as an alternative, as a way to continue struggling for revolution, but now under the new banner of jihad. 


\section{References}

Atkin, M. 1993. “Tajik National Identity." Iranian Studies 26 (1-2): 151-58.

Blank, S. J., ed. 2012. Russia's Homegrown Insurgency: Jihad in the North Caucasus. Carlisle Barracks, PA: US Army War College.

Boym, S. 2002. Obshchie mesta: Mifologiia povsednevnoi zhizni [Points of commonality: The mythology of everyday life]. Moscow: NLO.

Bustanov, A., and M. Kemper. 2015. "Islam i russkii iazyk: Sotsiolingvisticheskie aspekty stanovleniia obshcherossiiskogo islamskogo diskursa" [Islam and the Russian language: Sociological aspects of the emergence of the Russia-wide Islamic discourse]. Kazan Islamic Review 1: 211-21.

Bobrovnikov, V. 2011. “'Ordinary Wahhabism' versus 'Ordinary Sufism'? Filming Islam for Postsoviet Muslim Young People.” Religion, State \& Society 39: 281-301.

Bonnefoy, L. 2012. "Jihadi Violence in Yemen.” In Contextualising Jihadi Thought, edited by J. Deol and Z. Kazmi, 243-58. London: Hurst.

Bustanov, A., and M. Kemper. 2013. "The Russian Orthodox and Islamic Languages in the Russian Federation.” Slavica Tergestina 15: 259-77.

Coombs, D. S. 2011. "Entwining Tongues: Postcolonial Theory, Post-Soviet Literatures and Bilingualism in Chingiz Aitmatov's 'I dol'she veka dlitsia den'.' Journal of Modern Literature 34 (3): 47-64.

Cottee, S. 2011. "Jihadism as a Subcultural Response to Social Strain: Extending Marc Sageman's 'Bunch of Guys' Thesis.” Terrorism and Political Violence 23 (5): 730-51.

Dannreuther, R. 2010. "Islamic Radicalization in Russia: An Assessment." International Affairs 86 (1): 109-26.

Ditrych, O., and E. Souleimanov. 2008. "The Internationalisation of the Russian-Chechen Conflict: Myths and Reality.” Europe-Asia Studies 6o (7): 1199-1222.

Gambetta, D., and S. Hertog. 2016. Engineers of Jihad: The Curious Connection between Violent Extremism and Education. Princeton, NJ: Princeton University Press.

Garaev, D. 2017. "Jihad as Passionarity: Said Buriatskii and Lev Gumilev.” Islam and Christian-Muslim Relations 28 (2): 203-18.

Iandarbiev, Zelimkhan, 1996. Chechniia - bitva za svobodu [Chechnya: The Battle for Freedom]. Lviv.

Iandarbiev, Zelimkhan, 2016. “Kavkazskii uzel.” January 28, http:// www.kavkaz-uzel.eu/ articles/171845/.

Iarlykapov, A. 2014. "Islam i konflikt na Kavkaze" [Islam and the conflict in the Caucasus]. In Bol'shoi Kavkaz dvadtsat' let spustia: Resursy i strategii politiki i identichnos$t i$ [The greater Caucasus twenty years later: Resources and strategies of politics and identity], edited by G. Guseinov, 183-215. Moscow: NLO.

Kemper, M. 2012. “Jihadism: The Discourse of the Caucasus Emirate." In Islamic Authority and the Russian Language: Studies on Texts from European Russia, the North Caucasus and West Siberia, edited by A. K. Bustanov and M. Kemper, 265-93. Amsterdam: Uitgeverij Pegasus.

Kendall, E. 2016. “Jihadist Propaganda and Its Exploitation of the Arab Poetic Tradition.” In Reclaiming Islamic Tradition: Modern Interpretations of the Classical Heritage, edited by E. Kendall and A. Khan, 223-46. Edinburgh: Edinburgh University Press.

Knysh, A. "Islam and Arabic as the Rhetoric of Insurgency: The Case of the Caucasus Emirate." Studies in Conflict and Terrorism 35 (4): 315-37.

Kavkazcenter. 2005. "Razmyshleniia modzhakheda” [Thoughts of a Mujahid], November 8th. 
Kavkazcenter. 2006a. "Razmyshleniia modzhakheda” [Thoughts of a Mujahid], May 23 rd.

Kavkazcenter. 2006b. “Otvety Amira Seifullakh na voprosy musul'man” [Amir Sayfullah's answers to Muslims' questions], August 28th.

Lorenzo, V. 2007. “Current Trends in Jihadi Networks in Europe.” Terrorism Monitor 5 (20). Accessed February 4, 2011, http://www.jamestown.org/single/?no_ cache $=1 \&$ tx_ttnews\%5Btt_news\%5D $=4499$.

Mendelsohn, B. 2005. "Sovereignty under Attack: The International Society Meets the Al Qaeda Network." Review of International Studies 31 (1): 45-68.

Mutsuraev, Timur. 1998. Youtube, November 25, 2011, https://www.youtube.com/ watch?v=yRzabzzfKfo.

“My vziali v ruki oruzhie, chtoby ustanovit' zakony (interv'iu s Movladi Udugovym, Chast' 2)" [We have taken up arms to establish laws (an interview with Movladi Udugov)], 2008. Prague Watchdog, http://www.watchdog.cz/?show=000000-000015000006-000042\&lang=2.

"Nevskaia shkola" [The Nevsky School]. 1999. Soobshchenie, http://www.soob.ru/n/1999/2/ $\mathrm{mg} / \mathrm{o} /$.

Phillips, A. 2010. "The Protestant Ethic and the Spirit of Jihadism - Transnational Religious Insurgencies and the Transformation of International Orders." Review of International Studies 36 (2): 257-80.

Rasulov, I. 2016. "Dzhikhad na Severnom Kavkaze: Storonniki i protivniki” [Jihad in the Northern Caucasus: Supporters and detractors]. Official site of the press bureau of Vilayat Dagestan, November 28th, http://vd.ag/wp-content/ uploads/Knigi/896.pdf.

Rich, B., and D. Conduit. 2015. "The Impact of Jihadist Foreign Fighters on Indigenous Secular-Nationalist Causes: Contrasting Chechnya and Syria.” Studies in Conflict and Terrorism 38 (2): 113-31.

Roy, O. 2001. The Failure of Political Islam. Cambridge, MA: Harvard University Press.

Sageman, M. 2004. Understanding Terror Networks. Philadelphia: University of Pennsylvania Press.

Sagramoso, D. 2012. "The Radicalisation of Islamic Salafi Jamaats in the North Caucasus: Moving Closer to the Global Jihadist Movement?” Europe-Asia Studies 64 (3): 56195.

Sayfullah, A. 2007. "Dzhikhad protiv verootstupnikov" [Jihad against apostates]. Kavkazcenter, March 10.

Shlapentokh, D. 2011. "Jihadism in the Post-Soviet Era: The Case of Interaction of Theoretical and Practical Aspects of the Revolutionary Struggle." Iran and the Caucasus 15 (1-2): 275-98.

Shnirel'man, V. 2003. Voiny pamiati: mify, identichnost' i politika v Zakavkaz'e [Wars of memory: Myths, identity, and politics in Transcaucasia]. Moscow: Akademkniga.

Shnirel'man, V. 2006 “Lev Gumilev: Ot 'passionarnogo napriazheniia' do 'nesovmestimosti kul'tur" [Lev Gumilev: From "passionate tension” to "incompatibility of cultures”]. Etnograficheskoe obozrenie 3: 8-21.

Sokolov, D., and I. Starodubrovskaia, eds. 2013. Istoki konfliktov na Severnom Kavkaze [The sources of the conflicts in the Northern Caucasus]. Moscow: Delo.

Tishkov, V. 2001. Obshchestvo v vooruzhennom konflikte (etnografiia chechenskoi voiny) [Society in an armed conflict (an ethnography of the Chechen War)]. Moscow: Nauka.

“Udugov obvinil zapadnye SMI v iskazhenii suti ego 'total'noi voiny' protiv Rossii.” 2006. To.com. 24 April. https://obzor.westsib.ru/article/71061. 